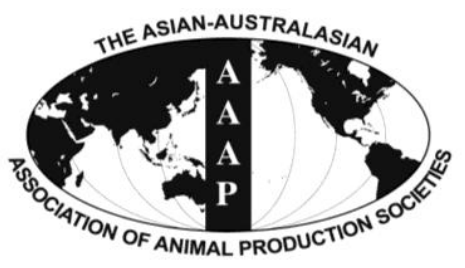

Asian-Aust. J. Anim. Sci.

Vol. 26, No. 4 : 463-469 April 2013

http://dx.doi.org/10.5713/ajas.2012.12576

www.ajas.info

pISSN 101 1-2367 elSSN 1976-5517

\title{
Association of the Porcine Cluster of Differentiation 4 Gene with T Lymphocyte Subpopulations and Its Expression in Immune Tissues
}

\author{
Jingen $\mathrm{Xu}^{\mathrm{a}}$, Yang Liu ${ }^{\mathrm{a}}$, Weixuan Fu, Jiying Wang, Wenwen Wang, Haifei Wang, Jianfeng Liu, \\ Xiangdong Ding and Qin Zhang* \\ Key Laboratory of Animal Genetics, Breeding and Reproduction, Ministry of Agriculture, \\ College of Animal Science and Technology, China Agricultural University, Beijing 100193, China
}

\begin{abstract}
Cluster of differentiation 4 (CD4) is mainly expressed on CD4 ${ }^{+} \mathrm{T}$ cells, which plays an important role in immune response. The aim of this study was to detect the association between polymorphisms of the CD4 gene and T lymphocyte subpopulations in pigs, and to investigate the effects of genetic variation on the CD4 gene expression level in immune tissues. Five missense mutations in the CD4 gene were identified using DNA pooling sequencing assays, and two main haplotypes (CCTCC and AGCTG) in strong linkage disequilibrium (with frequencies of $50.26 \%$ and $46.34 \%$, respectively) were detected in the population of Large White pigs. Our results indicated that the five SNPs and the two haplotypes were significantly associated with the proportions of $\mathrm{CD} 4{ }^{-} \mathrm{CD} 8^{-}$, $\mathrm{CD}^{+} \mathrm{CD}^{+}, \mathrm{CD}^{+} \mathrm{CD}^{-}, \mathrm{CD}^{+}$and $\mathrm{CD}^{+} / \mathrm{CD}^{+}$in peripheral blood $(\mathrm{p}<0.05)$. Gene expression analysis showed the mRNA level of the CD4 gene in thymus was significantly higher than that in lymph node and spleen $(\mathrm{p}<0.05)$. However, no significant difference was observed between animals with CCTCC/CCTCC genotype and animals with AGCTG/AGCTG genotype in the three immune tissues ( $>0.05$ ). These results indicate that the CD4 gene may influence $\mathrm{T}$ lymphocyte subpopulations and can be considered as a candidate gene affecting immunity in pigs. (Key Words: Pig, CD4, Polymorphisms, T lymphocyte subpopulations, Expression)
\end{abstract}

\section{INTRODUCTION}

T lymphocytes are important immune cells which play a central role in cell-mediated immunity (Fabbri et al., 2003). According to the differences in their cell surface molecules, $\mathrm{T}$ lymphocytes are divided into four subpopulations (CD4 $\mathrm{CD} 8, \mathrm{CD}^{-} \mathrm{CD}^{+}, \quad \mathrm{CD} 4^{+} \mathrm{CD} 8^{-}$and $\mathrm{CD}^{-} \mathrm{CD} 8^{+}$cells) (Saalmüller et al., 1989; Summerfield et al., 1996). Since the proportions of the $\mathrm{T}$ lymphocyte subpopulations in peripheral blood vary with health status, they can be regarded as important indexes reflecting the immune response capacity. Several studies have reported that the proportions of $\mathrm{T}$ lymphocyte subpopulations could change when pigs are treated with different antigens (Pauly et al., 1998; Appleyard et al., 2002).

CD4 consists of an $\mathrm{N}$-terminal extracellular domain, a transmembrane domain and an intracellular cytoplasmic tail (Moldovan et al., 2002). The function of the CD4 molecule

\footnotetext{
* Corresponding Author: Qin Zhang. Tel: +86-10-62732634, Fax: +86-10-62732634, E-mail: qzhang@ cau.edu.cn

${ }^{a}$ These authors contributed equally to this work.

Submitted Oct. 15, 2012; Accepted Dec. 17, 2012; Revised Jan. 4, 2013
}

is to enhance the activation and proliferation of $\mathrm{T}$ cells. Its extracellular domain binds to major histocompatibility complex (MHC) class II molecules, which can reinforce the $\mathrm{T}$ cell receptor (TCR) to recognize the peptide-MHC class II complexes (Doyle et al., 1987; Vignali et al., 1992; Wang et al., 2001). Its cytoplasmic tail interacts with tyrosine kinase $\mathrm{p} 56^{\text {lck }}$, which can promote signal transduction in $\mathrm{T}$ cells (Barber et al., 1989; Shaw et al., 1990). Moreover, CD4 is the receptor of human immunodeficiency virus (HIV) gp120 envelope glycoprotein (Wyatt et al., 1992). CD4 molecule is mainly expressed on the surface of mature CD4 cells. The primary role of $\mathrm{CD} 4^{+}$cells is to assist other immunocytes to execute functions in immune processes, including the maturation of $\mathrm{B}$ cells and activation of cytotoxic T lymphocytes (CTL). Furthermore, $\mathrm{CD}^{+}$cells have a powerful antitumor effect in addition to enhancing the activity of CTL to cope with tumors (Perez-Diez et al., 2007). Many diseases have been reported to be related to the count of CD4 $4^{+}$cells. For example, Banda et al. (1992) reported that patients infected with HIV were accompanied by a decrease of the number of $\mathrm{CD} 4^{+} \mathrm{T}$ cells, and Segalés et al. (2001) showed a significant reduction of $\mathrm{CD} 4^{+} \mathrm{T}$ cells in 
pigs suffering from postweaning multisystemic wasting syndrome.

As the CD4 gene encodes its protein which participates in cellular immunity, its polymorphisms have been reported in correlation with different human diseases, including type 1 diabetes (Kristiansen et al., 2004), multiple myeloma (Lee et al., 2010) and vitiligo (Zamani et al., 2010). It was also reported that the polymorphisms of the CD4 gene were associated with the somatic cell score in milk of dairy cattle (He et al., 2011). The CD4 gene can be taken as a vital candidate gene on account of its important function in porcine immunity. Therefore, identification of its variations correlated with $\mathrm{T}$ lymphocyte subpopulations could provide useful information for enhancing immune competence in pigs. In this study, we detected polymorphisms of the porcine CD4 gene, analyzed their associations with $\mathrm{T}$ lymphocyte subpopulations in Large White pigs, and investigated their effects on the mRNA expression level in immune tissues.

\section{MATERIAL AND METHODS}

\section{Experimental animals and phenotypes of $\mathbf{T}$ lymphocyte subpopulations}

The animals consisted of 382 Large White piglets raised at the experimental farm of the Institute of Animal Sciences, Chinese Academy of Agricultural Sciences, Beijing, China. All the piglets were vaccinated with Classical Swine Fever (CSF) live vaccine at the age of $21 \mathrm{~d}$. Blood samples were collected from each piglet at the age of $20 \mathrm{~d}$ (one day before the vaccination) and $35 \mathrm{~d}$ (two weeks after the vaccination) respectively. Ear tissue samples were collected for extracting genomic DNA. Thymus, lymph node and spleen were collected from piglets at the age of $35 \mathrm{~d}$, then rapidly frozen in liquid nitrogen and stored at $-80^{\circ} \mathrm{C}$.

$\mathrm{T}$ lymphocyte subpopulations in peripheral blood were measured by flow cytometry in the Xiyuan Hospital of China Academy of Chinese Medical Sciences, Beijing, China, and the detailed information on the measurement was described in our previous report ( $\mathrm{Lu}$ et al., 2011). Seven $\mathrm{T}$ lymphocyte subpopulation traits were defined: proportions of $\mathrm{CD} 44^{-} \mathrm{CD} 8^{-}, \mathrm{CD} 4^{+} \mathrm{CD} 8^{+}, \mathrm{CD} 4^{+} \mathrm{CD} 8^{-}, \mathrm{CD} 4$ $\mathrm{CD}^{+}, \mathrm{CD}^{+}, \mathrm{CD}^{+}$, and the ratio of $\mathrm{CD}^{+}$to $\mathrm{CD} 8^{+}$ $\left(\mathrm{CD} 4^{+} / \mathrm{CD}^{+}\right)$.

\section{DNA extraction and SNP identification}

Genomic DNA was extracted from ear tissue of each piglet by the standard phenol/chloroform method, and thirty samples with equal DNA concentration $(50 \mathrm{ng} / \mu \mathrm{l})$ were selected randomly to make a DNA pool. The amplified regions, including the regulatory region $(2,000 \mathrm{bp}$ upstream of the exon 1), all exonic and flanking intronic regions, were detected by DNA pooling sequencing assays in the
Table 1. Primers for detecting SNPs of the porcine CD4 gene

\begin{tabular}{|c|c|c|c|}
\hline Position & Primer sequence $\left(5^{\prime}-3^{\prime}\right)$ & $\operatorname{Tm}\left({ }^{\circ} \mathrm{C}\right)$ & $\begin{array}{l}\text { Product } \\
\text { size (bp) }\end{array}$ \\
\hline \multirow[t]{2}{*}{ Promoter 1} & CCAGGTCATGCCATTTTCTT & 57.5 & 620 \\
\hline & TGTTTCTGTTGAGGCAACCA & & \\
\hline \multirow[t]{2}{*}{ Promoter 2} & TGCCCTTGATGAAGCAGTAA & 57.5 & 534 \\
\hline & CTATGGTGCGGGTTTGATCT & & \\
\hline \multirow[t]{2}{*}{ Promoter 3} & AGATCAAACCCGCACCATAG & 59 & 581 \\
\hline & CCCGGATCTCTAATGAGCAC & & \\
\hline \multirow[t]{2}{*}{ Promoter 4} & TTCAAGTGGAGAAGCCCAGT & 60 & 678 \\
\hline & GGTCTCTCTTCCССTCTGCT & & \\
\hline \multirow[t]{2}{*}{ Exon 1} & GTGGTGACATTCTGGGCTCT & 59 & 372 \\
\hline & TCCAGCACATTCCAGCATAC & & \\
\hline \multirow[t]{2}{*}{ Exon 2, 3} & GGTTCTGCATGCTGAGTTCC & 64 & 554 \\
\hline & TAGGAGCTGGGCTCTGACAT & & \\
\hline \multirow[t]{2}{*}{ Exon 4} & GTATTTGGCGGGTAGGAGTG & 56 & 515 \\
\hline & GGAGGGTTTGAGGAGTTGTG & & \\
\hline \multirow[t]{2}{*}{ Exon 5} & GGGTCCTGGCTTCTTCTCTT & 62 & 386 \\
\hline & CCACACCAGCCACACTACAG & & \\
\hline \multirow[t]{2}{*}{ Exon 6} & TCTGCTCTTATCTCGTGCGG & 54.5 & 831 \\
\hline & GGCTGCCTCTTGGATGTCA & & \\
\hline \multirow[t]{2}{*}{ Exon 7} & CAATCGGAGCCACAGTCTCT & 58.5 & 563 \\
\hline & AACTGGGAGGGTCCCGTAGT & & \\
\hline \multirow[t]{2}{*}{ Exon 8} & GAGAGTACGTTGTGCCCTGA & 59 & 464 \\
\hline & AGGAGAGGGGTTGTGAAGGT & & \\
\hline \multirow[t]{2}{*}{ Exon 9} & TCTGTTTCTCGCTGGGTTCT & 58 & 461 \\
\hline & ССТСССТТСССТСТСТТСАС & & \\
\hline \multirow[t]{2}{*}{ Exon 10_1 } & AAGGCGTTGGGAAGGAAC & 61 & 605 \\
\hline & GTGTGTCTAGGGTGCCTGCT & & \\
\hline \multirow[t]{2}{*}{ Exon 10_2 } & ACTGACGGAGCCACAGACTC & 59 & 668 \\
\hline & GGCTATCAACTTTCGCAGGA & & \\
\hline \multirow[t]{2}{*}{ Exon $10 \_3$} & CTGGAATCCCTCCTTCATCA & 58 & 668 \\
\hline & ССТTTCССCACAGATCAGAA & & \\
\hline
\end{tabular}

CD4 gene. Primers (Table 1) for amplifying the CD4 gene from genomic DNA were designed using the Primer 3 software (http://frodo.wi.mit.edu/primer3/).

Polymerase chain reaction (PCR) was performed in a total volume of $25 \mu \mathrm{l}$, including $50 \mathrm{ng}$ DNA, $2.5 \mu \mathrm{l}$ $10 \times$ PCR buffer (15 mM MgCl 2$), 2 \mu \mathrm{dNTPs}(2.5 \mathrm{mM}$ each), $1 \mu \mathrm{l}$ each of forward and reverse primers $(10 \mu \mathrm{M}), 0.625$ units (U) of Taq DNA Polymerase (Takara Biotechnology Co., Ltd., China). The PCR cycling protocol was an initial denaturation at $94^{\circ} \mathrm{C}$ for $5 \mathrm{~min}, 35$ cycles of denaturation at $94^{\circ} \mathrm{C}$ for $35 \mathrm{~s}$, annealing at 54 to $64^{\circ} \mathrm{C}$ for $40 \mathrm{~s}$, and extension at $72^{\circ} \mathrm{C}$ for $45 \mathrm{~s}$, followed by a final extension at $72^{\circ} \mathrm{C}$ for $10 \mathrm{~min}$. PCR products were sequenced directly, and SNPs were identified using the Chromas 2.3.1 and the DNAMAN 6.0 software.

\section{SNPs genotyping}

Five missense mutations were found in coding regions of the CD4 gene, named SNP1, SNP2, SNP3, SNP4 and SNP5 respectively. SNP1, SNP2, SNP3 and SNP4 were genotyped by matrix-assisted laser desorption/ionization time-of-flight mass spectrometry (MALDI-TOF MS, 
Sequenom MassARRAY, Biao Miao Biological Technology Co., Ltd., China). SNP5 was genotyped by the derived cleaved amplified polymorphic sequence (dCAPS) method, for which the forward primer was 5'AAGCTGGGGAACCAGAGAAT-3', designed by the dCAPS Finder 2.0 software (Neff et al., 2002), and the reverse primer was 5'-TCCAGCAGGACTTTGTCTTTG-3', designed by the Primer Premier 5.0 software. Then PCRrestriction fragment length polymorphism (PCR-RFLP) method was adopted to genotype this SNP with restriction endonuclease Hinf I.

\section{RNA extraction and reverse transcription}

Total RNA was isolated from thymus, lymph node and spleen tissues using the Trizol reagent (Invitrogen, USA) and quantified using the NanoDrop ${ }^{\mathrm{TM}} 2000$ spectrophotometer (Thermo Scientific, USA). The RNA integrity was checked by $1 \%$ agarose gel electrophoresis before the first-strand cDNA was synthesized. The reaction reagents comprised: $1 \mu \mathrm{g}$ of total RNA, $1 \mu$ Oligo $(\mathrm{dT})_{15}$ primer $(50 \mu \mathrm{M}), 1 \mu \mathrm{l}$ dNTPs $(10 \mathrm{mM}$ each). They were incubated at $65^{\circ} \mathrm{C}$ for $5 \mathrm{~min}$, and then immediately put on ice for at least $2 \mathrm{~min}$. Afterwards, $4 \mu \mathrm{l} 5 \times$ primerscript buffer, $20 \mathrm{U}$ RNase inhibitor, $200 \mathrm{U}$ primerscript reverse transcriptase (Takara Biotechnology Co., Ltd., China) and RNase free $\mathrm{H}_{2} \mathrm{O}$ were added into above reagents to a final volume of $20 \mu \mathrm{l}$. At last, the mixtures were incubated at $42^{\circ} \mathrm{C}$ for $60 \mathrm{~min}$, and $70^{\circ} \mathrm{C}$ for $15 \mathrm{~min}$ according to the manufacturer's instructions.

\section{Quantitative real time PCR amplification}

Quantitative real time PCR (qPCR) was applied to analyze the expression level of the porcine CD4 gene using a LightCycler $^{\circledR} 480$ II instrument (Roche Diagnostics $\mathrm{GmbH}$, Germany). The qPCR reaction system contained 10 $\mu l$ of $2 \times$ SYBR green I mixture, $10 \mathrm{pM}$ each of the forward and reverse primers, $20 \mathrm{ng}$ of cDNA in a final volume of 20 $\mu \mathrm{l}$.

The primers for CD4 (GenBank accession number: AY515292.2) gene expression were: 5'GAGCGGATGTCTCAGATCAAG-3' and 5'GCCTCAGGTGAGGGAATAGTT-3'. Glyceraldehyde-3phosphate dehydrogenase (GAPDH) was used as an internal reference gene. The primers of the GAPDH gene were described by Zhou et al. (2012), and the sequences were: 5'ACTCACTCTTCTACTTTTGATGCT-3' and 5'-TGTTGC TGTAGCCAAATTCA-3'. The reaction conditions were followed by initial denaturation at $95^{\circ} \mathrm{C}$ for $10 \mathrm{~min}, 45$ cycles at $95^{\circ} \mathrm{C}$ for $10 \mathrm{~s}, 60^{\circ} \mathrm{C}$ for $10 \mathrm{~s}$ and $72^{\circ} \mathrm{C}$ for $10 \mathrm{~s}$. Each cDNA sample was carried out in triplicate, and the relative expression level of the CD4 gene was calculated using the $2^{-\Delta \Delta C t}$ method (Livak and Schmittgen, 2001).

\section{Statistical analysis}

The association analysis between each SNP and each of the seven T lymphocyte subpopulation traits was performed using the SAS 9.0 software based on the following mixed model:

$$
\mathrm{y}=\mu+\mathrm{Xa}+\mathrm{bf}+\mathrm{Tv}+\mathrm{Zu}+\mathrm{e}
$$

where $y$ is the vector of the phenotypic values for one of the $\mathrm{T}$ lymphocyte subpopulation traits measured at day $35 ; \mu$ is the overall mean; $a$ is the vector of fixed effects including sex, sampling batch and SNP genotype; $\mathrm{f}$ is the vector of the corresponding phenotypic values measured at day $20 ; \mathrm{b}$ is the regression coefficient; $\mathrm{v}$ is the vector of random litter effects; $u$ is the vector of random polygenic effects; $X, T$ and $\mathrm{Z}$ are incidence matrices for $\mathrm{a}, \mathrm{v}$ and $\mathrm{u}$ respectively; $\mathrm{e}$ is the vector of residual effects.

Linkage disequilibrium and haplotype analysis were performed using the Haploview 4.2 and the BEAGLE 3.3.2 software. The association of haplotype with the $\mathrm{T}$ lymphocyte subpopulation traits was analyzed using the same model as mentioned above, and multiple comparisons were tested using the Bonferroni correction.

\section{RESULTS}

\section{SNPs identification and genotyping}

A total of eight SNPs were identified in exon and intron regions of the CD4 gene by sequencing assays. Five of them are missense mutations (Table 2) which were selected for subsequent association study, although the synonymous mutations and variations outside coding regions might have potential functions. The genotype and allele frequencies of the five SNPs in the experimental animals are shown in Table 3. The allele frequencies of all SNP were around 50\%, and none of the SNPs significantly deviated from HardyWeinberg equilibrium $(\mathrm{p}>0.05)$.

\section{Association of CD4 gene polymorphisms with $\mathrm{T}$ lymphocyte subpopulation traits}

The results of association analysis of the five SNPs with the seven T lymphocyte subpopulation traits are presented in Table 4. All of them were significantly associated with $\mathrm{CD}^{-} \mathrm{CD}^{-}, \mathrm{CD}^{+} \mathrm{CD} 8^{-}, \mathrm{CD} 4^{+}$and $\mathrm{CD}^{+} / \mathrm{CD}^{+}(\mathrm{p}<0.05)$, but

Table 2. The information for five SNPs in the porcine CD4 gene

\begin{tabular}{lccc}
\hline Name & Position & $\begin{array}{c}\text { Nucleotide } \\
\text { substitution }\end{array}$ & $\begin{array}{c}\text { Amino acid } \\
\text { substitution }\end{array}$ \\
\hline SNP1 & Exon 3 & $\mathrm{C}<\mathrm{A}$ & T73K \\
SNP2 & Exon 4 & $\mathrm{C}<\mathrm{G}$ & T80S \\
SNP3 & Exon 6 & $\mathrm{C}<\mathrm{T}$ & P290L \\
SNP4 & Exon 7 & $\mathrm{C}<\mathrm{T}$ & A318V \\
SNP5 & Exon 7 & $\mathrm{G}<\mathrm{C}$ & M348I \\
\hline
\end{tabular}


Table 3. Genotype and allele frequencies of the CD4 gene polymorphisms in Large White pigs

\begin{tabular}{|c|c|c|c|c|c|c|c|c|}
\hline \multirow{2}{*}{ SNP } & \multicolumn{2}{|c|}{ Allele } & \multicolumn{3}{|c|}{ Genotype frequency (No. samples) } & \multicolumn{2}{|c|}{ Allele frequency } & \multirow{2}{*}{$\mathrm{p}$ value* } \\
\hline & 1 & 2 & 11 & 12 & 22 & 1 & 2 & \\
\hline$\overline{\mathrm{SNP} 1}$ & $\mathrm{C}$ & A & $0.2461(94)$ & $0.4633(177)$ & $0.2906(111)$ & 0.4777 & 0.5223 & 0.3771 \\
\hline SNP2 & $\mathrm{C}$ & G & $0.2199(84)$ & $0.4895(187)$ & $0.2906(111)$ & 0.4647 & 0.5353 & 0.9521 \\
\hline SNP3 & $\mathrm{T}$ & $\mathrm{C}$ & $0.2277(87)$ & $0.4817(184)$ & $0.2906(111)$ & 0.4686 & 0.5314 & 0.8139 \\
\hline SNP4 & $\mathrm{C}$ & $\mathrm{T}$ & $0.2382(91)$ & $0.5105(195)$ & $0.2513(96)$ & 0.4935 & 0.5065 & 0.9184 \\
\hline SNP5 & $\mathrm{C}$ & G & $0.2199(84)$ & $0.4869(186)$ & $0.2932(112)$ & 0.4634 & 0.5366 & 0.9198 \\
\hline
\end{tabular}

* $\mathrm{p}$ values from $x^{2}$ test for Hardy-Weinberg equilibrium.

Table 4. Effects of the CD4 gene polymorphisms on T lymphocyte subpopulations in Large White pigs (least squares means \pm standard errors)

\begin{tabular}{|c|c|c|c|c|c|c|c|c|}
\hline SNP & $\begin{array}{c}\text { Genotype } \\
\text { (No. samples) }\end{array}$ & $\mathrm{CD}^{-} \mathrm{CD} 8^{-}$ & $\mathrm{CD}^{+} \mathrm{CD}^{+}$ & $\mathrm{CD} 4^{+} \mathrm{CD} 8^{-}$ & $\mathrm{CD} 4^{-} \mathrm{CD} 8^{+}$ & $\mathrm{CD}^{+}{ }^{+}$ & $\mathrm{CD}^{+}$ & $\mathrm{CD}^{+} / \mathrm{CD}^{+}$ \\
\hline \multirow[t]{3}{*}{$\overline{\text { SNP1 }}$} & CC (94) & $33.09^{\mathrm{cB}}$ & 10.35 & $15.60^{\mathrm{A}}$ & 38.42 & $26.57^{\mathrm{A}}$ & 50.75 & $0.56^{\mathrm{A}}$ \\
\hline & $\mathrm{AC}(177)$ & $35.28^{\mathrm{bAB}}$ & 9.83 & $14.72^{\mathrm{A}}$ & 38.20 & $24.94^{\mathrm{A}}$ & 49.43 & $0.55^{\mathrm{A}}$ \\
\hline & $\mathrm{AA}(111)$ & $37.61^{\mathrm{aA}}$ & 9.21 & $12.79^{\mathrm{B}}$ & 39.38 & $22.20^{\mathrm{B}}$ & 48.33 & $0.47^{\mathrm{B}}$ \\
\hline \multirow[t]{3}{*}{ SNP2 } & $\mathrm{CC}(84)$ & $32.44^{\mathrm{cB}}$ & $10.52^{\mathrm{a}}$ & $15.95^{\mathrm{A}}$ & 38.37 & $27.18^{\mathrm{A}}$ & 51.03 & $0.57^{\mathrm{A}}$ \\
\hline & CG (187) & $35.49^{\mathrm{bAB}}$ & $9.79^{\mathrm{ab}}$ & $14.61^{\mathrm{A}}$ & 38.23 & $24.76^{\mathrm{B}}$ & 49.36 & $0.55^{\mathrm{A}}$ \\
\hline & GG (111) & $37.65^{\mathrm{aA}}$ & $9.19^{\mathrm{b}}$ & $12.76^{\mathrm{B}}$ & 39.38 & $22.14^{\mathrm{C}}$ & 48.31 & $0.47^{\mathrm{B}}$ \\
\hline \multirow[t]{3}{*}{ SNP3 } & TT (87) & $32.64^{\mathrm{cB}}$ & $10.56^{\mathrm{a}}$ & $15.79^{\mathrm{A}}$ & 38.41 & $27.04^{\mathrm{A}}$ & 51.04 & $0.57^{\mathrm{A}}$ \\
\hline & CT (184) & $35.43^{\mathrm{bA}}$ & $9.76^{\mathrm{ab}}$ & $14.66^{\mathrm{A}}$ & 38.21 & $24.79^{\mathrm{B}}$ & 49.33 & $0.55^{\mathrm{A}}$ \\
\hline & CC (111) & $37.64^{\mathrm{aA}}$ & $9.19^{\mathrm{b}}$ & $12.77^{\mathrm{B}}$ & 39.38 & $22.15^{\mathrm{C}}$ & 48.31 & $0.47^{\mathrm{B}}$ \\
\hline \multirow[t]{3}{*}{ SNP4 } & CC (91) & $33.01^{\mathrm{B}}$ & 10.26 & $15.65^{\mathrm{A}}$ & 38.47 & $26.53^{\mathrm{aA}}$ & 50.73 & $0.56^{\mathrm{a}}$ \\
\hline & CT (195) & $35.65^{\mathrm{A}}$ & 9.75 & $14.37^{\mathrm{AB}}$ & 38.52 & $24.56^{\mathrm{bAB}}$ & 49.50 & $0.54^{\mathrm{ab}}$ \\
\hline & TT (96) & $37.49^{\mathrm{A}}$ & 9.27 & $13.04^{\mathrm{B}}$ & 39.10 & $22.48^{\mathrm{cB}}$ & 48.05 & $0.48^{\mathrm{b}}$ \\
\hline \multirow[t]{3}{*}{ SNP5 } & CC (84) & $32.43^{\mathrm{cB}}$ & $10.52^{\mathrm{a}}$ & $15.96^{\mathrm{A}}$ & 38.37 & $27.18^{\mathrm{A}}$ & 51.02 & $0.57^{\mathrm{A}}$ \\
\hline & CG (186) & $35.45^{\mathrm{bA}}$ & $9.79^{\mathrm{ab}}$ & $14.63^{\mathrm{A}}$ & 38.23 & $24.75^{\mathrm{B}}$ & 49.35 & $0.55^{\mathrm{A}}$ \\
\hline & GG (112) & $37.70^{\mathrm{aA}}$ & $9.19^{\mathrm{b}}$ & $12.73^{\mathrm{B}}$ & 39.39 & $22.16^{\mathrm{C}}$ & 48.32 & $0.47^{\mathrm{B}}$ \\
\hline
\end{tabular}

$\overline{\mathrm{a}, \mathrm{b}, \mathrm{c}}$ Values with different superscripts are significantly different at $\mathrm{p}<0.05$. $^{\mathrm{A}, \mathrm{B}, \mathrm{C}}$ Values with different superscripts are significantly different at $\mathrm{p}<0.01$.

not with $\mathrm{CD} 4{ }^{-} \mathrm{CD} 8^{+}$and $\mathrm{CD}^{+}(\mathrm{p}>0.05)$. In addition, $\mathrm{SNP} 2$, SNP3 and SNP5 were significantly associated with the $\mathrm{CD} 4^{+} \mathrm{CD}^{+}(\mathrm{p}<0.05)$.

\section{Haplotypes and their association with $T$ lymphocyte subpopulation traits}

We analyzed the linkage disequilibrium (LD) between the five SNPs (Figure 1), and constructed haplotypes for them (Table 5). It showed that all these SNPs formed a single haplotype block with strong $\mathrm{LD}\left(\mathrm{r}^{2}>0.8\right)$, and two major haplotypes (AGCTG and CCTCC) were found in the experimental population with frequencies $50.26 \%$ and $46.34 \%$, respectively. We carried out association analyses for the two haplotypes, and it turned out that the associations of the haplotypes with the $\mathrm{T}$ lymphocyte subpopulations were basically consistent with that of single nucleotide polymorphism (Table 6). Except for $\mathrm{CD} 4{ }^{-} \mathrm{CD} 8^{+}$ and $\mathrm{CD}^{+}$, the haplotypes were significantly associated with all other traits $(\mathrm{p}<0.05)$ The samples carrying haplotypes CCTCC/CCTCC had higher values of $\mathrm{CD} 4^{+} \mathrm{CD} 8^{+}$, $\mathrm{CD} 4^{+} \mathrm{CD}^{-}, \mathrm{CD}^{+}$and $\mathrm{CD} 4^{+} / \mathrm{CD}^{+}$, and lower values of $\mathrm{CD} 4 \mathrm{CD}^{-}$than the samples with haplotypes

\section{AGCTG/AGCTG $(\mathrm{p}<0.05)$.}

\section{mRNA expression of the CD4 gene in immune tissues}

Two groups of piglets were selected, each containing four unrelated female individuals and all of them being haplotype homozygotes (AGCTG/AGCTG in one group

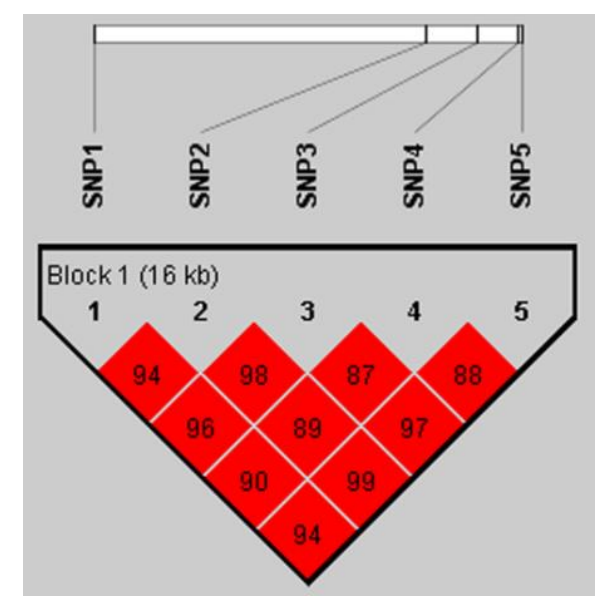

Figure 1. Linkage disequilibrium $\left(\mathrm{r}^{2}\right)$ among the five missense SNPs of the CD4 gene. 
Table 5. Haplotypes and their frequencies of the five SNPs

\begin{tabular}{lcc}
\hline Haplotype & SNPs & Frequency \\
\hline Hap1 & AGCTG & 0.5026 \\
Hap2 & CCTCC & 0.4634 \\
Hap3 & AGCCG & 0.0196 \\
Hap4 & CGCCG & 0.0092 \\
Hap5 & CGTTG & 0.0039 \\
Hap6 & CCTCG & 0.0013 \\
\hline
\end{tabular}

and CCTCC/CCTCC in another). The CD4 mRNA expression was analyzed in thymus, lymph node and spleen of the individuals in the two groups. The CD4 mRNA was detected in all the three immune tissues (Figure 2). The relative expression level in thymus was significantly higher than that in lymph node and spleen $(\mathrm{p}<0.05)$, while there was no significant difference between lymph node and spleen ( $p>0.05$ ). However, no significant differences of the CD4 mRNA level were detected in the three tissues between the two groups $(\mathrm{p}>0.05)$.

\section{DISCUSSION}

Polymorphisms of the CD4 gene have been reported in sheep (Boscariol et al., 2006) and goat (Wang et al., 2011). In swine, the polymorphisms of the CD4 gene have been reported only in miniature swine so far (Sundt et al., 1992; Gustafsson et al., 1993). Sundt et al. (1992) identified polymorphisms in exon 3 and exon 4 and argued that they were naturally occurring and did not have an effect on interacting with MHC class II molecules, while Gustafsson et al. (1993) considered that these variations were likely to have functions, because most of the mutations were located in a loop region and this part of the human CD4 gene might bind to the HIV gp120 protein and MHC class II. In this study, we screened all exons of the CD4 gene in Large White pigs and found five missense mutations in our samples. Among them, SNP1 and SNP2 were the same as Gustafsson et al. (1993) reported. Zerbib et al. (1994) reported that enhancement of $\mathrm{T}$ cell activation depended on the extracellular and transmembrane domains of CD4. Similarly, Viqnali et al. (1994) further found that the extracellular domain of CD4 was crucial to assist TCR recognize peptides. Other studies also showed that the extracellular portion of CD4 interacted with MHC class II molecules and TCR (Moebius et al., 1993; Viqnali and

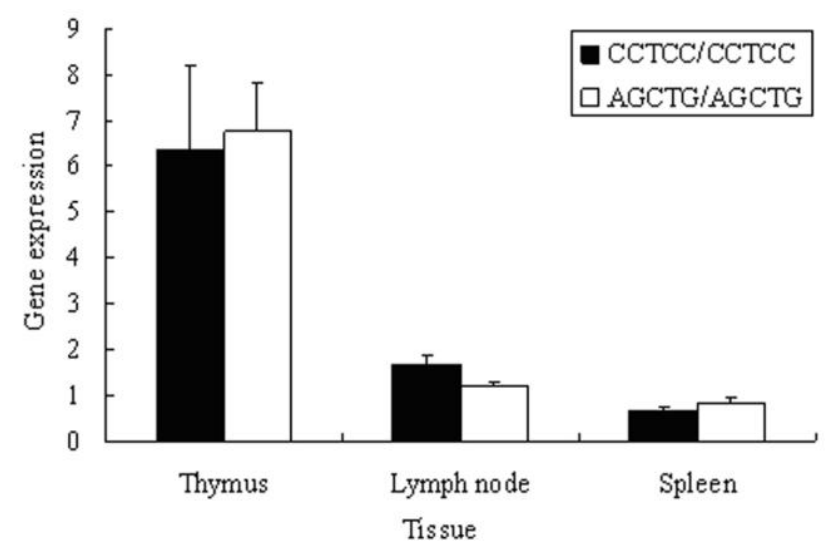

Figure 2. The expression of the CD4 gene in three immune tissues of animals with CCTCC/CCTCC $(n=4)$ and AGCTG/AGCTG (n $=4)$.

Viqnali, 1999), which was essential for T cell activation. In addition, the extracellular portion of CD4 could form homodimers to enhance immune response (Maekawa et al., 2006). All the five missense mutations found in this study are located in the extracellular domain of CD4, suggesting that they may impact the function of CD4 by altering its abilities to bind ligand or mediate dimerization.

It is very meaningful to identify genetic variants controlling immune traits in porcine breeding for disease resistance. In the present study, we firstly investigated effects of the CD4 gene on T lymphocyte subpopulations in pigs, and found the CD4 gene was significantly associated with partial components of T cells. Because the five SNPs were in nearly complete linkage and formed two major haplotypes in our population, which enabled the results of haplotype association study to be almost identical to that of a single nucleotide polymorphism. The CD4 was able to bind MHC class II molecules to reinforce $\mathrm{T}$ cell activation, but their interaction could evidently lessen when mutated the CD4 protein (Fleury et al., 1996). At the same time, the survival of resting $\mathrm{CD}^{+}$cells also required for the interactions between CD4 and MHC class II molecules (Maroto et al., 1999). In addition, T cell homeostasis needs the regulation of CD4 molecules (Strong et al., 2001). It was notable that the significant association traits were related to $\mathrm{CD}^{+}$cells except for $\mathrm{CD}^{-} \mathrm{CD}^{-}$in our results, therefore, we inferred that missense mutations of the CD4 gene could change the function of the CD4 molecule and even regulate the $\mathrm{CD}^{+}$cell counts, which possibly caused

Table 6. Effects of haplotypes in the CD4 gene on T lymphocyte subpopulations in Large White pigs (least squares means \pm standard errors)

\begin{tabular}{lrcccccc}
\hline Haplotypes (No. samples) & $\mathrm{CD}^{-} \mathrm{CD}^{-}$ & $\mathrm{CD}^{+} \mathrm{CD}^{+}$ & $\mathrm{CD}^{+} \mathrm{CD}^{-}$ & $\mathrm{CD}^{-} \mathrm{CD}^{+}$ & $\mathrm{CD}^{+}$ & $\mathrm{CD}^{+}$ & $\mathrm{CD}^{+} / \mathrm{CD}^{+}$ \\
\hline CCTCC/CCTCC $(84)$ & $32.35^{\mathrm{cB}}$ & $10.98^{\mathrm{aA}}$ & $16.15^{\mathrm{A}}$ & 38.41 & $28.19^{\mathrm{A}}$ & 51.12 & $0.59^{\mathrm{A}}$ \\
AGCTG/CCTCC $(177)$ & $35.26^{\mathrm{bA}}$ & $10.28^{\mathrm{aAB}}$ & $14.78^{\mathrm{A}}$ & 38.16 & $25.68^{\mathrm{B}}$ & 49.39 & $0.56^{\mathrm{A}}$ \\
AGCTG/AGCTG (96) & $37.60^{\mathrm{aA}}$ & $9.19^{\mathrm{BB}}$ & $12.72^{\mathrm{B}}$ & 39.05 & $21.80^{\mathrm{C}}$ & 48.01 & $0.47^{\mathrm{B}}$ \\
\hline
\end{tabular}

$\overline{a, b, c}$ Values with different superscripts are significantly different at $\mathrm{p}<0.05$; ${ }^{\mathrm{A}, \mathrm{B}, \mathrm{C}}$ Values with different superscripts are significantly different at $\mathrm{p}<0.01$. 
the CD4 genetic variants to be correlated with the components of $\mathrm{T}$ cells. Furthermore, the polymorphisms of the CD4 gene were in high linkage disequilibrium and maybe they linked with unknown causative variations to influence observed traits. However, the relationship between polymorphisms of CD4 gene and T lymphocyte subpopulations in peripheral blood requires confirmation in a larger pig population. T lymphocytes play an essential role in combating antigens, and the changes of their components could be as an important immune index for disease prognosis. For example, the $\mathrm{CD} 4^{+} / \mathrm{CD}^{+}$ratio of neonatal pigs was reported to reduce in comparison to those uninfected with porcine reproductive and respiratory syndrome virus (Feng et al., 2002). Our results showed that the haplotypes CCTCC/CCTCC had a potential effect of increasing $\mathrm{CD} 4^{+}$cell counts and the $\mathrm{CD} 4^{+} / \mathrm{CD}^{+}$ratio, but whether the pigs with haplotypes CCTCC/CCTCC had a relatively better immune capacity requires further confirmation.

Missense mutations change amino acids and can alter the function of protein, and they also can impact on gene expression (Vasilopoulos et al., 2007). CD4 is the characteristic molecule on the surface of $\mathrm{CD}^{+} \mathrm{T}$ cell, and $\mathrm{T}$ lymphocytes primarily settle in the thymus and peripheral lymphoid tissues (Charerntantanakul and Roth, 2006), so the expression of CD4 was detected only in immune tissues. In order to study the potential function of mutations, we analyzed the mRNA level differences of the CD4 gene in pigs with different haplotype homozygotes. The qPCR results indicated that the mRNA expression of the CD4 gene had a spatial feature in different porcine immune tissues. The relative expression level in the thymus was significantly higher than that in lymph node and spleen ( $\mathrm{p}<0.05)$, which might be due to many of the immature CD4 $\mathrm{T}$ cells in the thymus not migrating into peripheral lymphoid tissues at the piglet stage. In addition, pigs with genotype CCTCC/CCTCC and genotype AGCTG/AGCTG had different phenotypic values, but the expression of the CD4 gene had no significant difference between the two group pigs in the three immune tissues ( $p>0.05$ ). Missense mutation could significantly affect protein activity but not mRNA expression levels (Chen et al., 2004). Our results also showed the mutation did not affect the mRNA expression level, however, considering the important function of CD4 in cellular immunity, the mechanisms affecting the $\mathrm{T}$ lymphocyte subpopulations are worth further studying.

In summary, we identified five missense mutations in the CD4 gene, and found two main haplotypes CCTCC and AGCTG in high linkage disequilibrium in Large White pig population. Furthermore, the SNPs and haplotypes were significantly associated with partial $\mathrm{T}$ lymphocyte subpopulation traits, but the mRNA expression level of the
CD4 gene had no significant differences between haplotypes CCTCC/CCTCC and AGCTG/AGCTG in three immune tissues. Our results showed that the CD4 gene could affect $\mathrm{T}$ lymphocyte subpopulations, and it should be regarded as a candidate gene for immune capacity in pigs.

\section{ACKNOWLEDGEMENTS}

This work was supported by the National Major Special Project on New Varieties Cultivation for Transgenic Organisms (2009ZX08009-146B), and the China Postdoctoral Science Foundation Funded Project (2012T50164).

\section{REFERENCES}

Appleyard, G. D., S. E. Furesz and B. N. Wilkie. 2002. Blood lymphocyte subsets in pigs vaccinated and challenged with Actinobacillus pleuropneumoniae. Vet. Immunol. Immunopathol. 86:221-228.

Banda, N. K., J. Bernier, D. K. Kurahara, R. Kurrle, N. Haigwood, R. P. Sekaly and T. H. Finkel. 1992. Crosslinking CD4 by human immunodeficiency virus gp120 primes $\mathrm{T}$ cells for activation-induced apoptosis. J. Exp. Med. 176:1099-1106.

Barber, E. K., J. D. Dasgupta, S. F. Schlossman, J. M. Trevillyan and C. E. Rudd. 1989. The CD4 and CD8 antigens are coupled to a protein-tyrosine kinase $\left(\mathrm{p} 56^{\mathrm{lck}}\right)$ that phosphorylates the CD3 complex. Proc. Natl. Acad. Sci. USA. 86:3277-3281.

Boscariol, R., J. Pleasance, D. M. Piedrafita, H. W. Raadsma and T. W. Spithill. 2006. Identification of two allelic forms of ovine CD4 exhibiting a $\mathrm{Ser}^{183} / \mathrm{Pro}^{183}$ polymorphism in the coding sequence of domain 3. Vet. Immunol. Immunopathol. 113:305312.

Charerntantanakul, W. and J. A. Roth. 2006. Biology of porcine T lymphocytes. Anim. Health. Res. Rev. 7:81-96.

Chen, J., B. K. Lipska, N. Halim, Q. D. Ma, M. Matsumoto, S. Melhem, B. S. Kolachana, T. M. Hyde, M. M. Herman, J. Apud, M. F. Egan, J. E. Kleinman and D. R. Weinberger. 2004. Functional analysis of genetic variation in Catechol-OMethyltransferase (COMT): Effects on mRNA, protein, and enzyme activity in postmortem human brain. Am. J. Hum. Genet. 75:807-821.

Doyle, C. and J. L. Strominger. 1987. Interaction between CD4 and class II MHC molecules mediates cell adhesion. Nature 330:256-259.

Fabbri, M., C. Smart and R. Pardi. 2003. T lymphocytes. Int. J. Biochem. Cell. Biol. 35:1004-1008.

Feng, W. H., M. B. Tompkins, J. S. Xu, T. T. Brown, S. M. Laster, H. X. Zhang and M. B. McCaw. 2002. Thymocyte and peripheral blood $\mathrm{T}$ lymphocyte subpopulation changes in piglets following in utero infection with porcine reproductive and respiratory syndrome virus. Virology 302:363-372.

Fleury, S., B. Huang, A. Zerbib, G. Croteau, E. O. Long and R. P. Sekaly. 1996. Mutations in human CD4 impair the functional interaction with different human and mouse class II isotypes and alleles. J. Immunol. 156:1848-1855.

Gustafsson, K., S. Germana, T. M. Sundt, D. H. Sachs and C. LeGuern. 1993. Extensive allelic polymorphism in the CDR2- 
like region of the miniature swine CD4 molecule. J. Immunol. 151:1365-1370.

He, Y., Q. Chu, P. Ma, Y. Wang, Q. Zhang, D. Sun, Y. Zhang, Y. Yu and Y. Zhang. 2011. Association of bovine CD4 and STAT5b single nucleotide polymorphisms with somatic cell scores and milk production traits in Chinese Holsteins. J. Dairy Res. 78:242-249.

Kristiansen, O. P., A. E. Karlsen, Z. M. Larsen, J. Johannesen, F. Pociot and T. Mandrup-Poulsen. 2004. Identification of a type 1 diabetes-associated CD4 promoter haplotype with high constitutive activity. Scand. J. Immunol. 59:582-591.

Lee, K. M., D. Baris, Y. Zhang, H. D. Hosgood, I. Menashe, M. Yeager, S. H. Zahm, S. S. Wang, M. P. Purdue, S. Chanock, T. Zheng, N. Rothman and Q. Lan. 2010. Common single nucleotide polymorphisms in immunoregulatory genes and multiple myeloma risk among women in Connecticut. Am. J. Hematol. 85:560-563.

Livak, K. J. and T. D. Schmittgen. 2001. Analysis of relative gene expression data using real-time quantitative PCR and the 2 (Delta Delta C(T)) method. Methods 25:402-408.

Lu, X., J. F. Liu, Y. F. Gong, Z. P. Wang, Y. Liu and Q. Zhang. 2011. Mapping quantitative trait loci for $\mathrm{T}$ lymphocyte subpopulations in peripheral blood in swine. BMC. Genet. 12:79.

Maekawa, A., B. Schmidt, B. Fazekas de St Groth, Y. H. Sanejouand and P. J. Hogg. 2006. Evidence for a domainswapped CD4 dimer as the coreceptor for binding to class II MHC. J. Immunol. 176:6873-6878.

Maroto, R., X. Shen and R. König. 1999. Requirement for efficient interactions between CD4 and MHC class II molecules for survival of resting $\mathrm{CD}^{+} \mathrm{T}$ lymphocytes in vivo and for activation-induced cell death. J. Immunol. 162:5973-5980.

Moebius, U., P. Pallai, S. C. Harrison and E. L. Reinherz. 1993. Delineation of an extended surface contact area on human CD4 involved in class II major histocompatibility complex binding. Proc. Natl. Acad. Sci. USA. 90:8259-8263.

Moldovan, M. C., A. Yachou, K. Lévesque, H. Wu, W. A. Hendrickson, E. A. Cohen and R. P. Sékaly. 2002. CD4 dimers constitute the functional component required for $\mathrm{T}$ cell activation. J. Immunol. 169:6261-6268.

Neff, M. M., E. Turk and M. Kalishman. 2002. Web-based primer design for single nucleotide polymorphism analysis. Trends Genet. 18:613-615.

Pauly, T., M. König, H. J. Thiel and A. Saalmüller. 1998. Infection with classical swine fever virus: effects on phenotype and immune responsiveness of porcine $\mathrm{T}$ lymphocytes. J. Gen. Virol. 79:31-40.

Perez-Diez, A., N. T. Joncker, K. Choi, W. F. Chan, C. C. Anderson, O. Lantz and P. Matzinger. 2007. CD4 cells can be more efficient at tumor rejection than CD8 cells. Blood 109:5346-5354.

Saalmüller, A., W. Hirt and M. J. Reddehase. 1989. Phenotypic discrimination between thymic and extrathymic $\mathrm{CD} 4{ }^{-} \mathrm{CD}^{-}$and $\mathrm{CD} 4^{+} \mathrm{CD}^{+}$porcine T lymphocytes. Eur. J. Immunol. 19:20112016.

Segalés, J., F. Alonso, C. Rosell, J. Pastor, F. Chianini, E. Campos, L. López-Fuertes, J. Quintana, G. Rodríguez-Arrioja, M. Calsamiglia, J. Pujols, J. Domínguez and M. Domingo. 2001. Changes in peripheral blood leukocyte populations in pigs with natural postweaning multisystemic wasting syndrome (PMWS). Vet. Immunol. Immunopathol. 81:37-44.
Shaw, A. S., J. Chalupny, J. A. Whitney, C. Hammond, K. E. Amrein, P. Kavathas, B. M. Sefton and J. K. Rose. 1990. Short related sequences in the cytoplasmic domains of CD4 and CD8 mediate binding to the amino-terminal domain of the $\mathrm{p} 56^{\mathrm{lck}}$ tyrosine protein kinase. Mol. Cell. Biol. 10:1853-1862.

Strong, J., Q. Wang and N. Killeen. 2001. Impaired survival of T helper cells in the absence of CD4. Proc. Natl. Acad. Sci. USA. 98:2566-2571.

Summerfield, A., H. J. Rziha and A. Saalmüller. 1996. Functional characterization of porcine $\mathrm{CD} 4^{+} \mathrm{CD} 8^{+}$extrathymic $\mathrm{T}$ lymphocytes. Cell. Immunol. 168:291-296.

Sundt, T. M., C. LeGuern, S. Germana, C. V. Smith, K. Nakajima, J. K. Lunney and D. H. Sachs. 1992. Characterization of a polymorphism of $\mathrm{CD} 4$ in miniature swine. J. Immunol. 148:3195-3201.

Vasilopoulos, Y., M. J. Cork, D. Teare, I. Marinou, S. J. Ward, G. W. Duff and R. Tazi-Ahnini. 2007. A nonsynonymous substitution of cystatin A, a cysteine protease inhibitor of house dust mite protease, leads to decreased mRNA stability and shows a significant association with atopic dermatitis. Allergy 62:514-519.

Vignali, D. A., J. Moreno, D. Schiller and G. J. Hämmerling. 1992. Species-specific binding of CD4 to the $\beta 2$ domain of major histocompatibility complex class II molecules. J. Exp. Med. 175:925-932.

Vignali, D. A. and J. L. Strominger. 1994. Amino acid residues that flank core peptide epitopes and the extracellular domains of CD4 modulate differential signaling through the $\mathrm{T}$ cell receptor. J. Exp. Med. 179:1945-1956.

Vignali, D. A. and K. M. Vignali. 1999. Profound enhancement of $\mathrm{T}$ cell activation mediated by the interaction between the TCR and the D3 domain of CD4. J. Immunol. 162:1431-1439.

Wang, J. H., R. Meijers, Y. Xiong, J. H. Liu, T. Sakihama, R. Zhang, A. Joachimiak and E. L. Reinherz. 2001. Crystal structure of the human CD4 N-terminal two-domain fragment complexed to a class II MHC molecule. Proc. Natl. Acad. Sci. USA. 98:10799-10804.

Wang, L., J. Fan, M. Yu, S. Zheng and Y. Zhao. 2011. Association of goat (Capra hircus) CD4 gene exon 6 polymorphisms with ability of sperm internalizing exogenous DNA. Mol. Biol. Rep. 38:1621-1628.

Wyatt, R., M. Thali, S. Tilley, A. Pinter, M. Posner, D. Ho, J. Robinson and J. Sodroski. 1992. Relationship of the human immunodeficiency virus type 1 gp120 third variable loop to a component of the CD4 binding site in the fourth conserved region. J. Virol. 66:6997-7004.

Zamani, M., M. A. Tabatabaiefar, S. Mosayyebi, A. Mashaghi and P. Mansouri. 2010. Possible association of the CD4 gene polymorphism with vitiligo in an Iranian population. Clin. Exp. Dermatol. 35:521-524.

Zerbib, A. C., A. B. Reske-Kunz, P. Lock and R. P. Sékaly. 1994. CD4-mediated enhancement or inhibition of $\mathrm{T}$ cell activation does not require the CD4: p56 ${ }^{\text {lck }}$ association. J. Exp. Med. 179:1973-1983.

Zhou, C., Z. Liu, J. Jiang, Y. Yu and Q. Zhang. 2012. Differential gene expression profiling of porcine epithelial cells infected with three enterotoxigenic Escherichia coli strains. BMC Genomics 13:330. 